Grete Swensen and Joar Skrede

\title{
Industrial heritage as a culturally sustainable option in urban transformation
}

\author{
The case of Skien and Moss
}

\begin{abstract}
Industrial heritage represents an opportunity for architects and designers to combine a building's robust form with creative solutions. A former methanol factory in Skien used as art hall, and a former paper mill in Moss used as a music venue, exemplify the ways in which cultural provisions for a diverse urban population can be accommodated. We examined the kinds of cultural provisions industrial buildings offer and how industrial heritage's tolerance level is met. The results are discussed in light of the societal responsibility to find long-lasting, sustainable solutions in urban development.
\end{abstract}

Keywords: cultural sustainability, industrial heritage, urban transformation, art, popular culture

\section{Introduction}

Although generally considered part of a central epoch in a city's economic history, industrial buildings are seldom defined as cultural heritage in terms of conservation orders. Nevertheless, such buildings have potential for architects and designers, who see options to combine the building's robust form with creative solutions. Two former industrial buildings are used in this paper to exemplify how a wide spectrum of cultural provisions for a diverse urban population can be met, and how the urban transformation of industrial buildings can contribute to cultural sustainability, as well as to environmental, economic and social sustainability.

The following research questions were raised:

- What cultural provisions do such buildings offer?

- How do these cultural venues reach a diverse population?

- How are their limits of tolerance as industrial heritage met?

- How do these enterprises relate to the contemporary policies of coupling (linking) culture and commerce?

The results will be discussed in view of two perspectives: The need to find long-lasting, sustainable solutions in urban development is a pivotal societal responsibility. Moreover, these venues will be viewed in light of political recommendations in white papers and official documents, where culture is considered part of a larger creative industry. Culture can be used as a concept to describe both a sector-specific activity and different life forms. In this paper, culture is mainly used in the first sense.

We will start by problematising issues related to the overarching concepts of heritage and culture and by explaining the approaches we have chosen. In the presentation of two cultural venues situated in different Norwegian cities, we highlight some of the planning intentions of the property developers, followed by an introduction to the venues, both situated in old industrial buildings. In the discussion, we compare the decisions that have been made in the two cases in view of cultural sustainability. 


\section{Linking heritage, culture and diversity in sustainable ways}

Cities have always played a privileged role as centres of cultural and economic activity (Scott, 2000 , p. 2). The significance of culture in urban regeneration processes is now widely recognised as a driving force in inter-urban competition. Cities use culture to polish their image and jump-start investment (Zukin, 2010, p. 231). This is the case in Scandinavia as it is elsewhere in Europe. Vitality is considered a positive characteristic that many cities seek to generate. A varied urban culture has become an attraction in itself, and activities geared towards adding a versatile profile to small and mid-size Norwegian towns are encouraged. Cultural venues are sometimes established as a way to rejuvenate areas that have been emptied of former activities. They can also be used as a form of 'magnet' to attract new functions to areas under development. This paper focuses mainly on the second variant, where former industrial buildings used as cultural arenas are being incorporated into new, larger development projects ('Klosterøya' in Skien, and 'Verket' in Moss).

\section{Industrial heritage}

Due to major economic restructuring since the 1960s, major industries have either become redundant or have moved their production abroad. Their former sites have changed character, from derelict, redundant areas to potential locations for future development. They can be used for various functions - residential, commercial or cultural - but often all three functions are considered likely to be mutually beneficial and are thus viewed in combination (Swensen \& Berg, 2017; Swensen \& Stenbro, 2013, 2015).

Because many years have passed since the factories closed down, more people have become aware of the value such buildings can hold. Where adaptive reuse of industrial buildings has a special relevance, it is partly connected to 'rediscovering' them as historical buildings, and partly because they have a shape and size appropriate for new creative uses (e.g., added ceiling height compared to most new buildings). The argument that these areas possess special qualities of cultural heritage value has gained weight because they reflect an industrial era in a city's history. They fill a function as memories of a not-too-distant past. It is no longer just cultural heritage enthusiasts who have realised that historic buildings have potential. New trends in art and architecture support such views (Fragner, 2012, p. 116). Their distinctive 'raw' quality and their particular architectural language are appreciated in their own right and help to create a fascination for what some would call industry's aesthetics (Berg, 2017; Fragner, 2012; Uffelen, 2010).

\section{Culture, creative art forms and diversity}

After Landry and Bianchini (1995) introduced the concept of 'the Creative City', researchers have discussed the ways in which the rise of creative industries has affected cities' profiles, including urging regeneration (see, for instance, Flew, 2014; Hesmondhalgh, 2008; Oliveira \& Paulino, 2017; Pratt, 2015; Richards \& Wilson, 2006). We use creative industries primarily as a backdrop to highlight the link between culture and regeneration. This coupling appears in various ways in Norwegian towns and cities to advance sustainable urban transformation processes.

A link between cultural life and business development was clearly present in several Norwegian White Papers, official reports, action plans, draft resolutions, etc., from various ministries from the middle of the 2000s (e.g., Ministry of the Climate and Environment, 20042005; Ministry of Culture, 2004-2005; Ministry of Culture, Ministry of Trade and Industry \& Ministry of Local Government and Regional Development, 2007; Ministry of Culture, 2013; Ministry of Culture, Ministry of Trade and Industry \& Ministry of Local Government and Regional Development, 2013; Ministry of Culture, 2017). Recently, more emphasis has been placed on considering the effects of demographic changes, immigration and globalisation, each of which affect the public use of cultural services. A prerequisite for a democratic society is to 
make room for a multitude of voices (Arts Council of Norway, 2013; Ministry of Culture, 2013).

Diversity can be used to refer to a wide range of expressions of art and creative activities, but it is often used in policy documents to describe intentions to reach - and hopefully integrate - an urban population increasingly diverse in gender, age, religion and ethnicity. We will use diversity in two ways: to illustrate the various ways 'culture' is used and to examine whether the user groups of the cultural venues in question have a diverse character.

In a series of official cultural policy documents, at a national level, democratisation and integration are important guiding principles. There are, however, few studies that have examined the relationship between policy guidelines and practical implementation at a local level. One such study of cultural activities among a highly diverse group of young people in Drammen - a city 40 kilometres south-west of Oslo with 116,000 inhabitants - has been carried out (Haugsevje, 2016). The study showed a high degree of convergence of positive goals between different sectors, and the cultural work at the municipal level managed to couple pedagogic, social and integration objectives. Another survey of immigrants' cultural venues, carried out in five municipalities south-east of the capital (Amin \& Ingdal, 2009), found that a rather low proportion of the participants were immigrants. A wide definition of culture was used, covering a vast range of venues - from sport to brass bands to traditional and modern forms of artistic expression. The reasons for the low participation rates were several (a lack of Norwegian, of information about accessible cultural activities, of money, or of spare time due to working hours).

\section{Cultural sustainability}

There are several interpretations of what sustainability means. Often, sustainable development amounts to a reassurance that we can have it all: economic growth, environmental conservation and social justice (Dryzek, 2005, p. 132; Skrede, 2013, p. 2). These three priority areas have been reflected in different sustainability slogans, such as the three P's of sustainability, 'Planet, People, Profits', or the three E's of sustainability, 'environmental responsibility, social equity and economic growth' (Benton-Short \& Short, 2008, p. 442; Elkington, 1998; Skrede, 2016, p. 416). Humans have acquired a habit of planned obsolescence that generates waste and the overspending of materials and energy (Skjerven \& Reitan, 2017). Thus, reusing redundant industrial buildings for new purposes can in many cases prove to be environmentally sustainable. Renovation and adaptive reuse have also shown themselves to be economically sustainable (Rypkema, 2006). If we plan inclusively, we can also fill former industrial buildings with new functions that cater to social sustainability. Recently, however, several scholars have argued that cultural issues should also be included in the sustainability model one way or another (e.g., Dessein, Soini, Fairclough, \& Horlings, 2015; Hawkes, 2001; Nurse, 2006; Skjerven \& Reitan, 2017; Skrede, 2013, 2014, 2016). One version of the argument is that culture constitutes the fourth pillar of sustainable development.

How does cultural sustainability become relevant? We ask what cultural content the fourth pillar can add to sustainable development if we adopt the four-pillar model. For our purpose, we will use former industrial buildings as examples. If we consider a building's purely physical functions, such as the provision of shelter and amenities offered by a historic building, these services could just as well be provided by another, newly built structure lacking any cultural content. However, if something is lost by substituting the building in question, we have identified cultural content that a new building cannot replicate (Skrede \& Berg, 2018, p. 6; Throsby, 2012, pp. 50-51). It is this 'cultural surplus' that makes some buildings worthy of protection by law. In this paper, we will argue that industrial heritage is also well suited to house cultural practices - namely, a diverse range of creative and artistic activities.

We will underpin this argument by delving into our two case studies - in Skien and Moss. By using two specific buildings as cases, we will look closer at the choices that are made 
concerning these buildings, as well as the plans for their integration into the new, larger neighbourhoods under development.

\section{Methods}

The methods used in our study comprised semi-structured interviews with local government employees - two in Skien and two in Moss. The interviews lasted about 1.5-2 hours each. In Moss, we also interviewed a property developer. We consulted public documents and websites to trace the local industrial history behind the regeneration taking place, and we visited the sites in question to observe the material and cultural transformation occurring.

\section{Case 1: The Spirit factory, Skien}

Table 1. Some milestones in the industrial period at Union Co. Source: Ottersland, 2015.

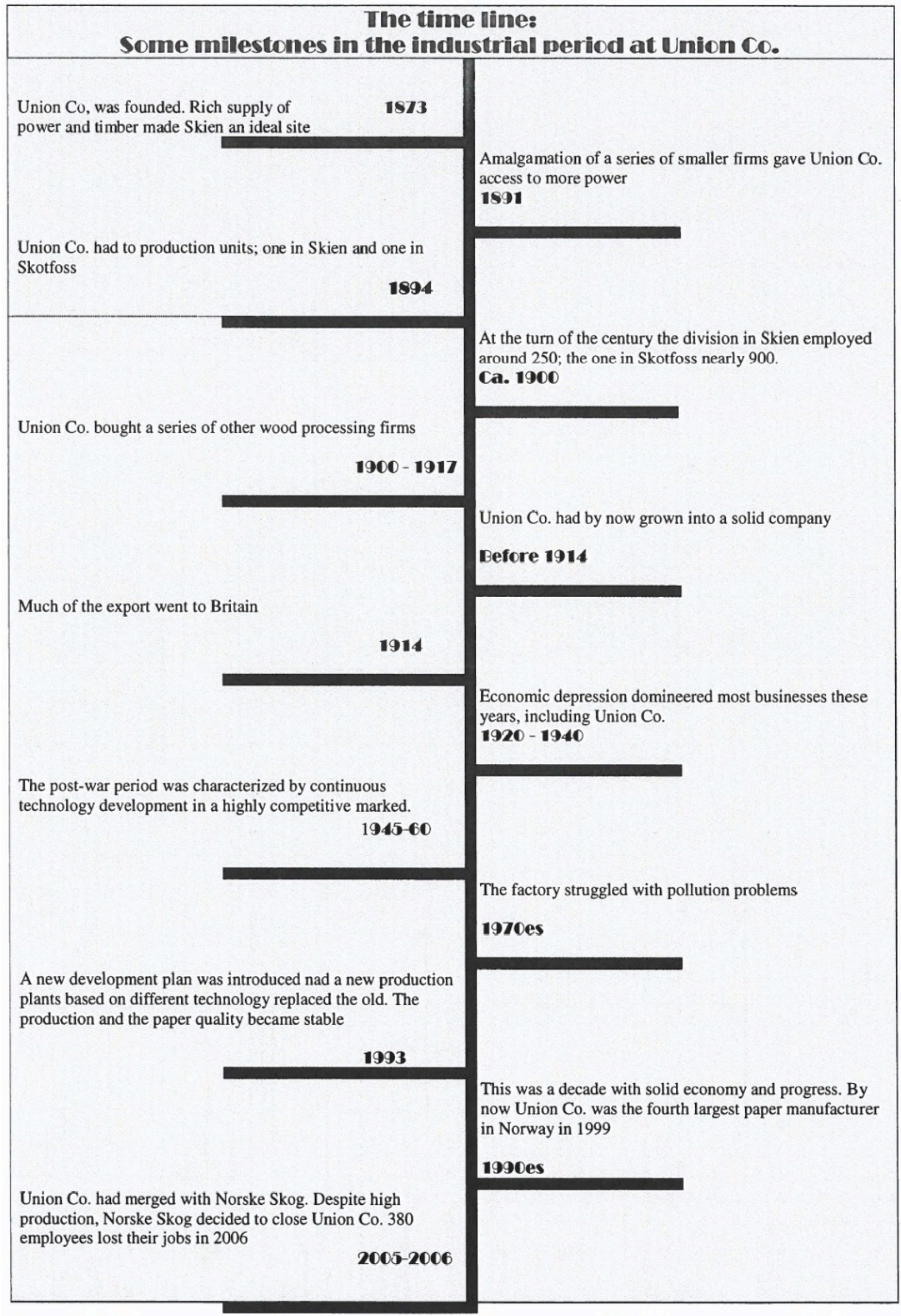




\section{The urban context}

'Spriten Kunsthall' - The Spirit factory - is an art initiative in which the municipality of Skien is strongly involved. Situated in an old industrial building, it has become a focal point in a new urban neighbourhood being developed on a large former brownfield at Klosterøya (the Monastery Island), a 15-minute walk from the city centre. Skien has approximately 54,000 inhabitants and is situated 130 kilometres south-west of Oslo. Skien is an old industrial city. The first industrial companies from the 1850s were involved in hydropower and wood processing (see Table 1, Figure 1). The name Klosterøya stems from the Monastery of Gimsøy, which according to tradition was founded around the mid-twelfth century. Most of the traditional industries have closed down; today, Skien is primarily a commercial and administrative centre.

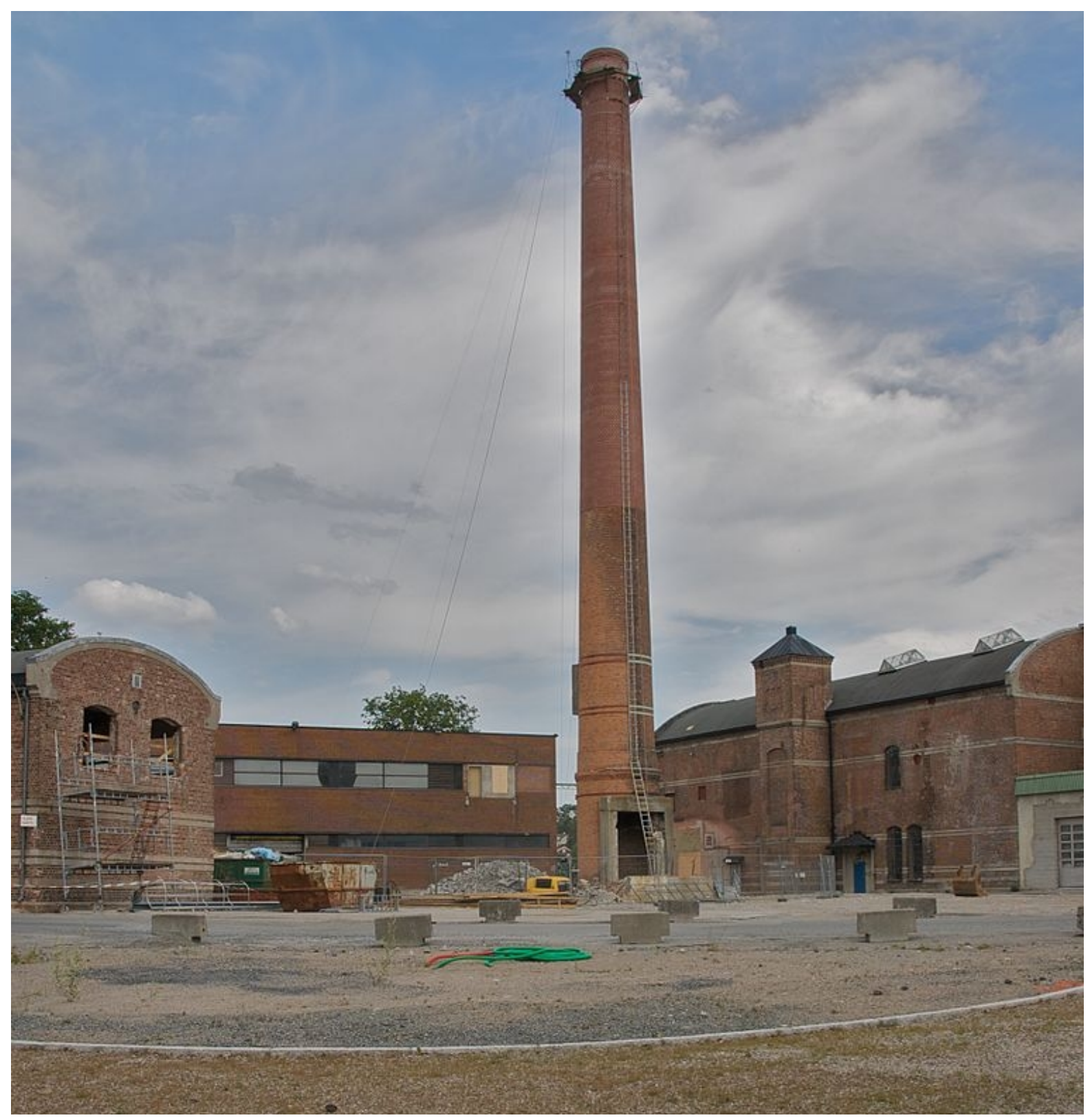

Figure 1. Many of the buildings from Union Co. were demolished. 'The old guardhouse' was one of the exceptions (left). Photo: Bitjungle, CC BY-SA 3.0 Creative Commons. 


\section{Larger plans for the urban transformation at Klosteroya}

The factory contained several buildings at Klosterøya and had 359 employees when it was closed. The whole area is now undergoing rapid transformation. Klosterøya is divided by a rather heavily trafficked road; the sides are generally referred to as Klosterøya east and west. While most of the firms and cultural activities are situated on the eastern side, most of the residential development is taking place on the western side (Figure 2).

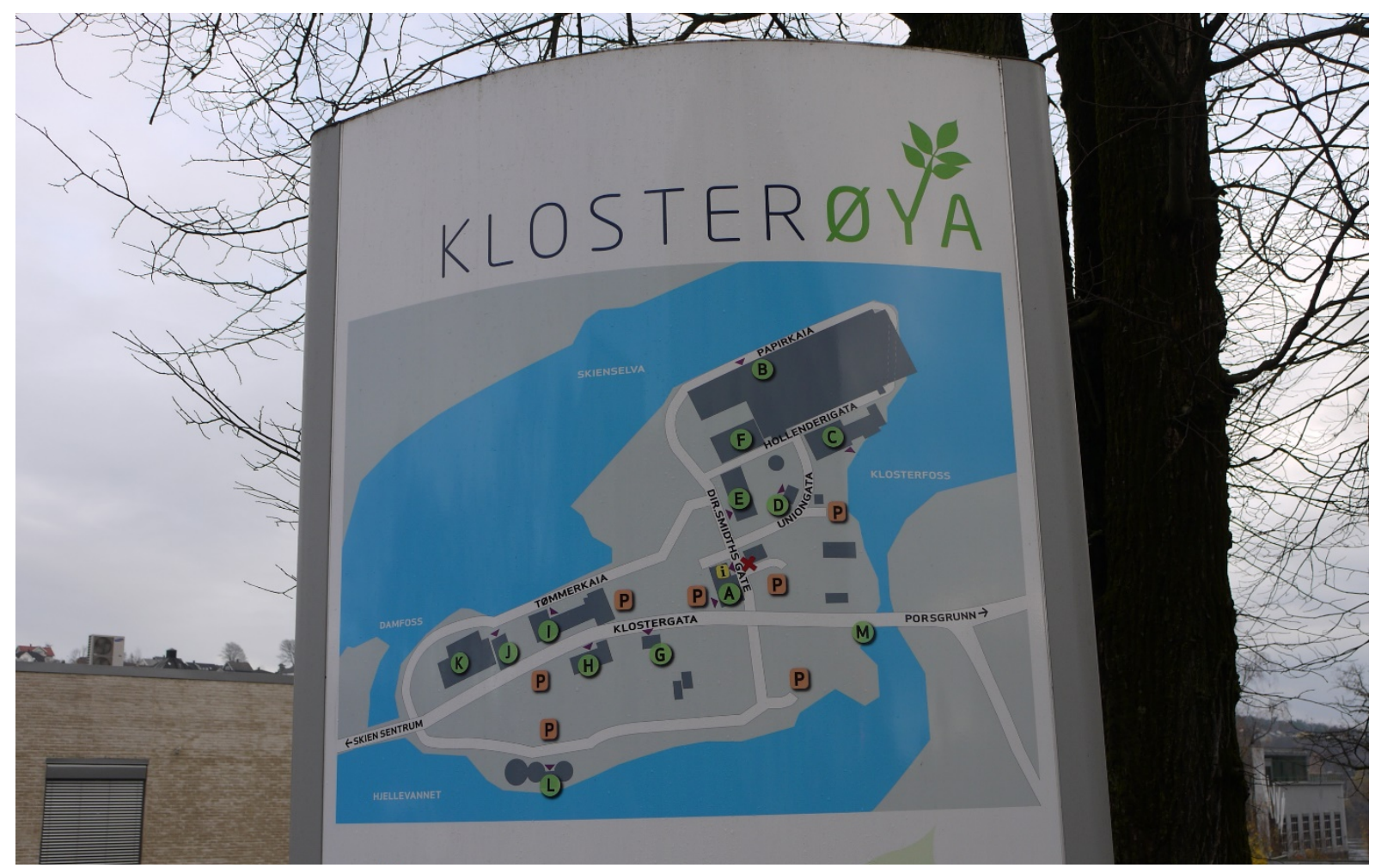

Figure 2. The map illustrates the layout of Klosterøya. Klostergata is the main artery that divides the area into its two main parts. Photo: NIKU.

The largest owner today is Bratsberg Gruppen, which bought the former industrial site at Klosterøya in 2011. When the transformation plans started in Klosterøya east, Bratsberg was the only owner; but recently, another property developer has bought several of the properties, including Spritfabrikken. On the internet, the eastern area is described as a commercial park and is profiled as an 'attractive area for commercial firms, housing and visitors' (Bratsberggruppen, n.d.). The enterprises situated here cover a wide spectrum of activities. Among private firms, we find various consultancies, information and communication technology firms, and company promoters, as well as health, training and welfare services. Five public services have their main office here. The owners have emphasised the mix of old and new buildings that the area offers. The old red brick building, named 'Gamle Vakta' (The Old Guardhouse), was built in 1916 and is ascribed experiential values by the owner. It is described as 'an historic and architectural pearl totally restored to accommodate modern office requirements'. It covers $200 \mathrm{~m}^{2}$ and was fully restored in 2009 (Bratsberggruppen, n.d.). The local theatre, Teater Ibsen, has fairly recently moved out of Gamle Vakta and into a new building. Another old building, formerly used for industrial cleaning processes, houses Eventyrfabrikken, a play and adventure centre for children, demonstrating the diversity of targeted audiences and functions. Much is expected of the new college built on the main site of the former paper mill, which is due to open when school starts in autumn 2018. The college is built to accommodate 1,150 students and 160 employees. 
The residential development of Klosterøya west is scheduled to proceed in several phases; the first was finished in 2014 and the second in 2016, with a total of five buildings comprising 100 apartments. When the plan is complete, there should be 300 apartments. The development is described as an environmentally friendly project, and its close proximity to the city centre minimises the need to use private cars. A children's playground is located centrally, between the buildings. The location near Hjellevannet provides many flats with good views. The pathways under construction in the area are intended to retain as much of the original forest as possible. A nature path will be laid out around Hjellevannet, and a pedestrian pathway into the town centre is nearly ready, making it possible to avoid the heavily trafficked artery. In its internet presentation, the project is described as 'spectacular' because the apartment blocks integrate old buildings: a former biological water purification installation featuring a façade decorated with five large sculptures, inspired by galleon figures. The net-based brochure informs us that 'old and new are well combined', and 'This is the quality the market knows how to evaluate' (Bratsberggruppen, n.d.).

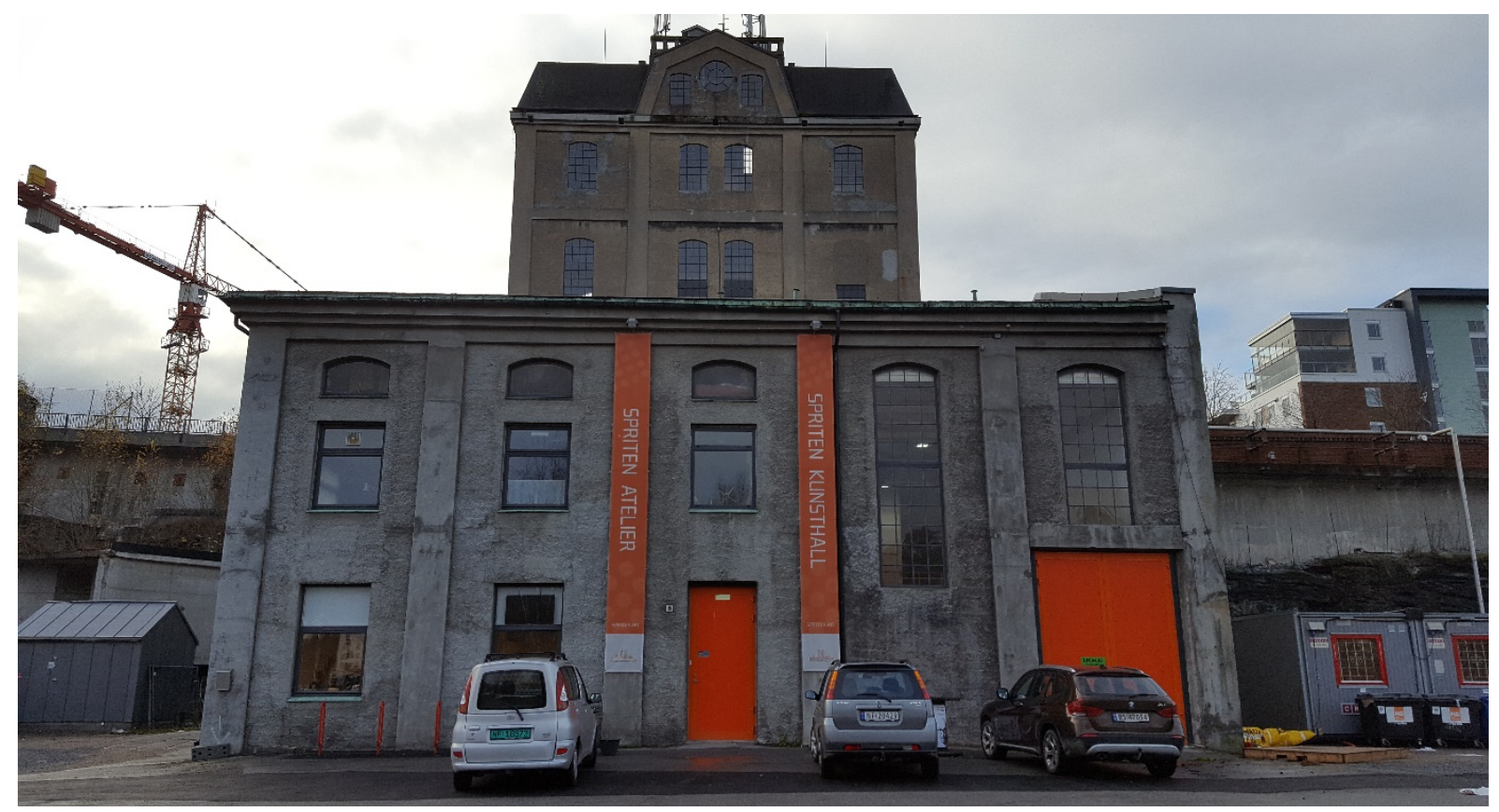

Figure 3. The main entrance to 'Spriten Kunsthall' is from the riverbank. It is a tall building and functions as landmark. Photo: NIKU.

\section{Spriten Kunsthall - The Spirit factory}

One of the most conspicuous buildings in the new transformation area is the 100-year old methanol factory. The large tower building previously contained brewery tanks, while the lower building fronting the tower was used for storage and exports. Since Norske Skog sold the old industrial buildings, they have been owned by different private property developers; the present owner is Steinar Moe Property. In 2006, Skien established the 'Kunstnerbyen' (The City of Artists) project, with the goal of revitalising Skien as a lively and engaging city of culture by attracting visitors (Skien Municipality, 2017) (respondents 1 and 2). As part of the strategy, the municipality hired the Spirit factory for artistic purposes. After renovating parts of the building's interior, 'Spriten Kunsthall' opened in 2012 as a gallery exhibiting contemporary and experimental art. In addition, the upper stories were turned into several ateliers that artists can use for creative purposes (Figure 3, 4, 5). 


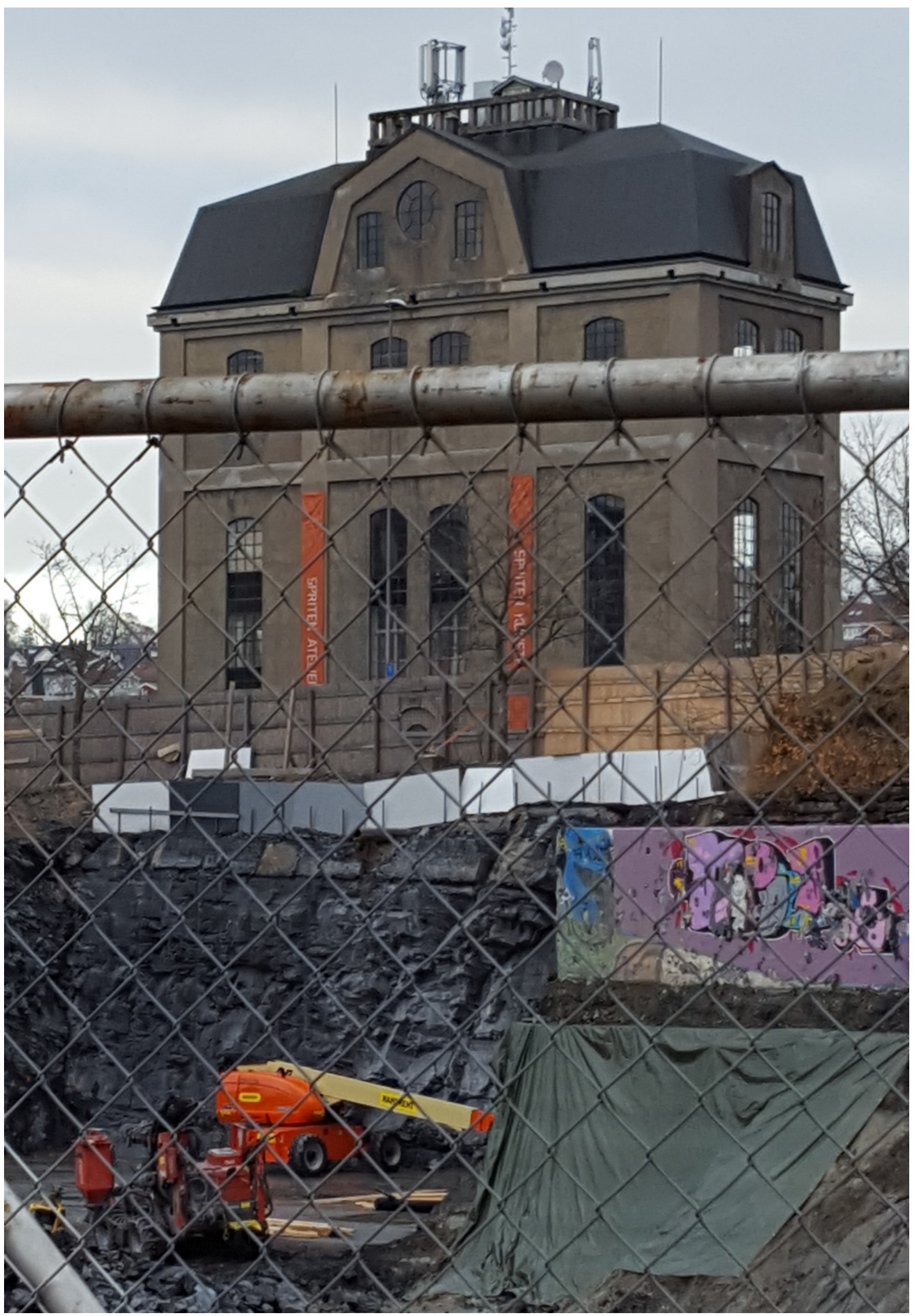

Figure 4. 'Spriten Kunsthall' towering in the background while construction work is taking place at Klosterøya Vest. Photo: NIKU. 


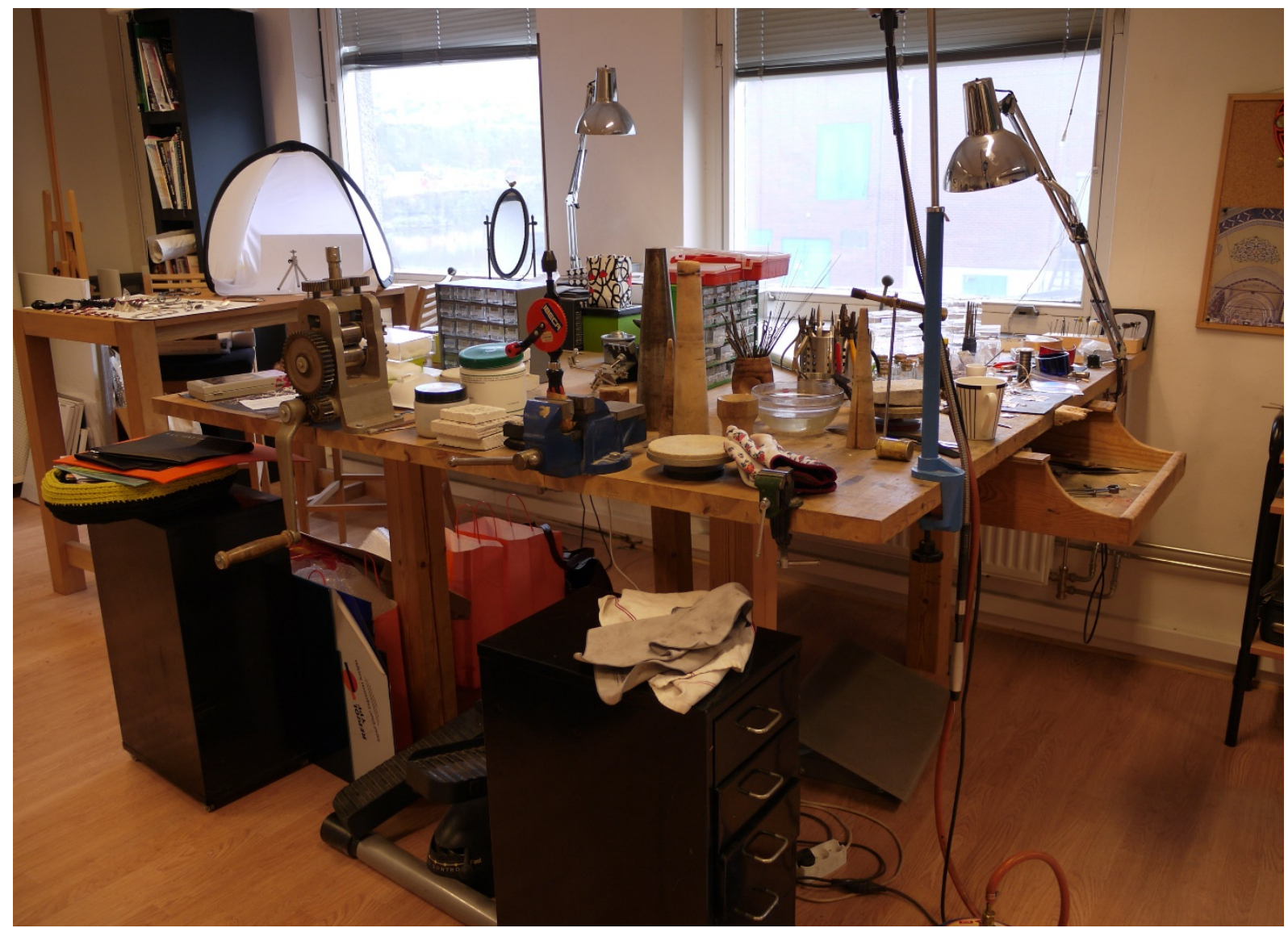

Figure 5. Skien municipality receives a rather symbolic rent from 11 diverse professional artists as part of the municipality's strategy to promote professional art. A silver smith / jewellery artist rents this studio. Photo: NIKU.

Representatives from Skien municipality cite the unique history of the building as an element that adds to the creative work taking place inside the old Spirit factory. They argue that the premises would not have had the same appeal without the hundred years that have passed. The building's distinct architecture/aesthetics has given it a historical quality that cannot readily be found in new buildings, and its longevity has inscribed the building into the collective memory of the locals. This is in line with the non-substitutability principle in 'strong' sustainability that a cultural surplus might not be readily substitutable by a new structure (Throsby, 2012, pp. 50-51). Although new buildings designed for accommodating artworks are practical (heating, air conditioning, noise reduction, etc.), the architectural qualities of industrial buildings can provide an exciting contrast between the old and the new. New buildings designed for art tend to present themselves more as a blank canvas. The Spirit factory's exhibition room offers some unique qualities; however, the representatives from the municipality also stress that artists and curators must work with the building to release its full potential. If they manage to succeed in releasing the potential, they can create synergies between the building and the artworks that a new building could not. In autumn 2017, the art hall housed a photo exhibition about street art and graffiti. The project leader engaged a local graffiti artist to decorate a full wall in the hall as an addition to the exhibition (Figure 6). It will be painted over when the exhibition closes, as an expression of the essence of street art and its processual character and temporality (respondent 1). This project is a concrete example of how the artist-building synergies function in practice. 


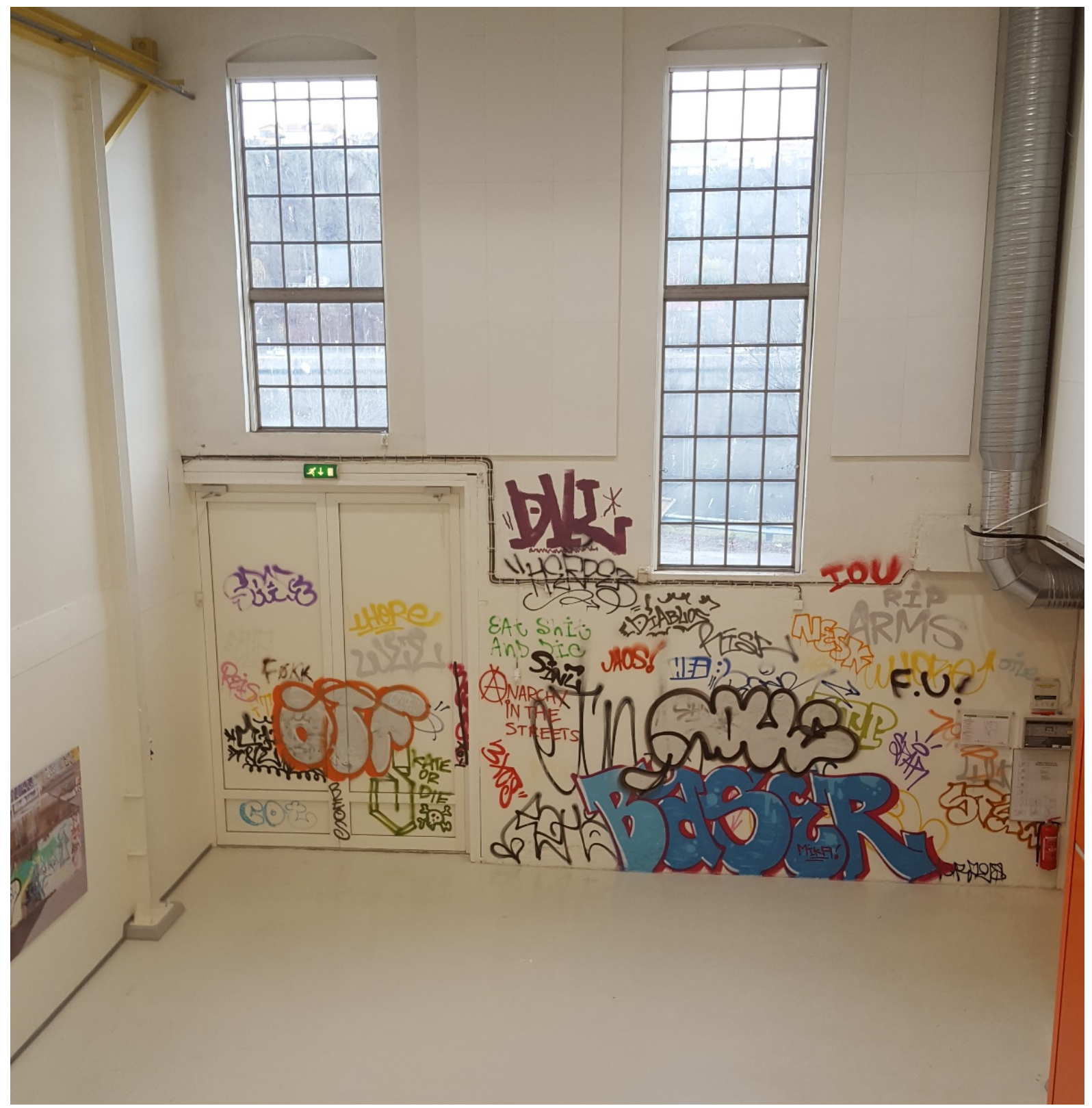

Figure 6. The exhibition hall was decorated by a local graffiti artist, with the artist name Rehab, when a photo exhibition opened in autumn 2017. Photo: NIKU.

\section{Case 2: Verket Scene, Moss \\ The urban context}

The building where the 'Verket Scene' cultural venue is located was previously a paper and cellulose factory that belonged to M. Peterson \& Søn (Figure 7). It is situated in an area undergoing comprehensive transformation in the northern part of the city centre. The river, with its impressive waterfall, provides the natural southern border, while the fjord with the former disembarkation harbour defines the border in the west.

Moss is located 60 kilometres south-east of Oslo, and the municipality has 33,000 inhabitants. Modern industrialisation started in Moss in the last third of the 1800s, with the establishment of a series of industrial firms (canned food factory, oil cloth factory, papermill and glass production) (see Table 2). Industry still provided 10 percent of the jobs in Moss in 2015. Major construction works on the railway connecting Moss to Oslo are being carried out to shorten the 45 -minute journey by 10 minutes, which will likely make Moss more attractive 
to commuters working in the Oslo region. The oldest remains of industry stem from Moss's iron works, which began operations in 1704 and closed in 1876. The main building, Konventionsgaarden, is listed, while the dwellings, situated in the street 'Verket' where the workers at Verket lived, have been preserved.

Table 2: Some milestones in the industrial period in M. Peterson \& Søn. Source: Østfoldmuseene, 2015.

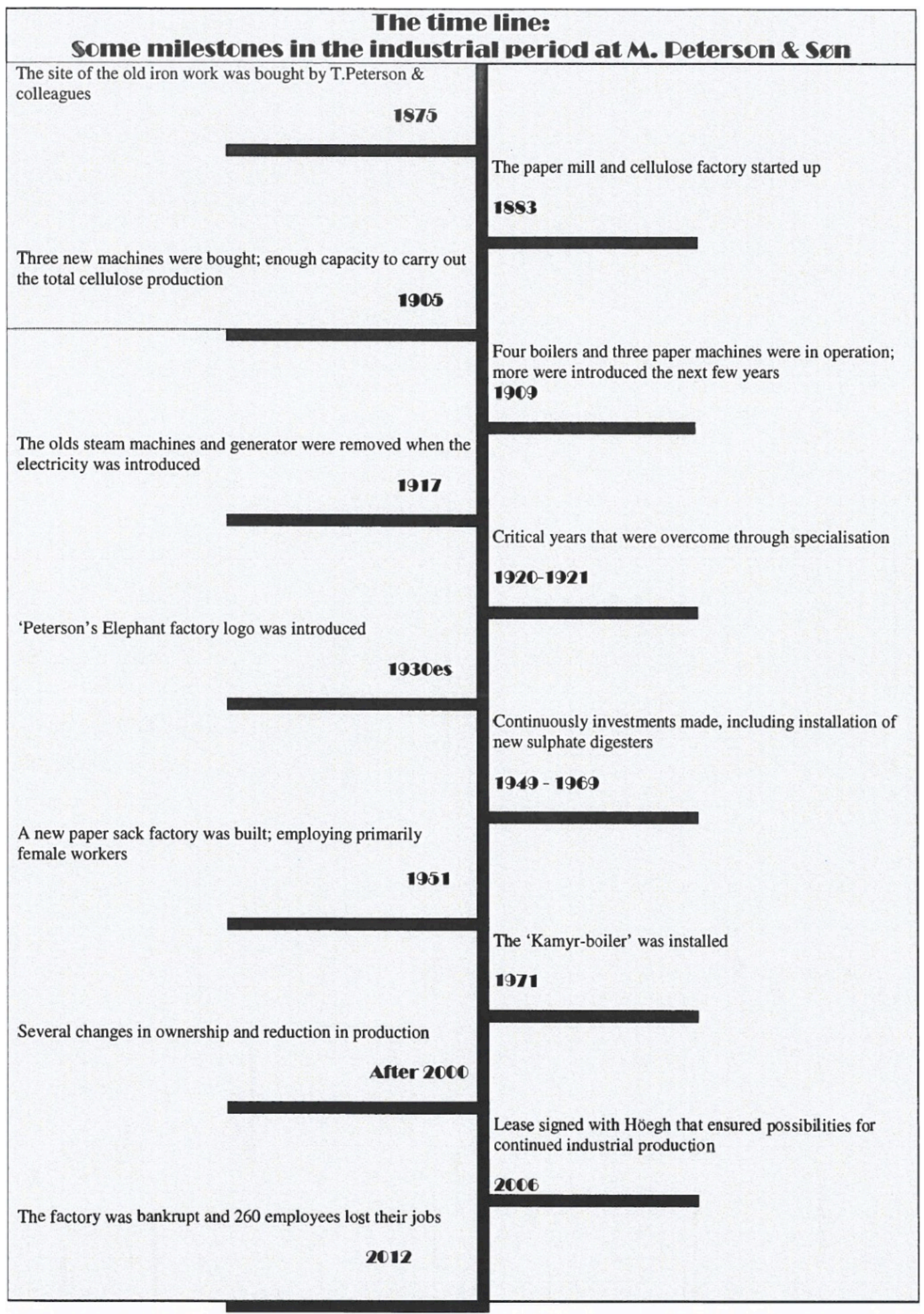




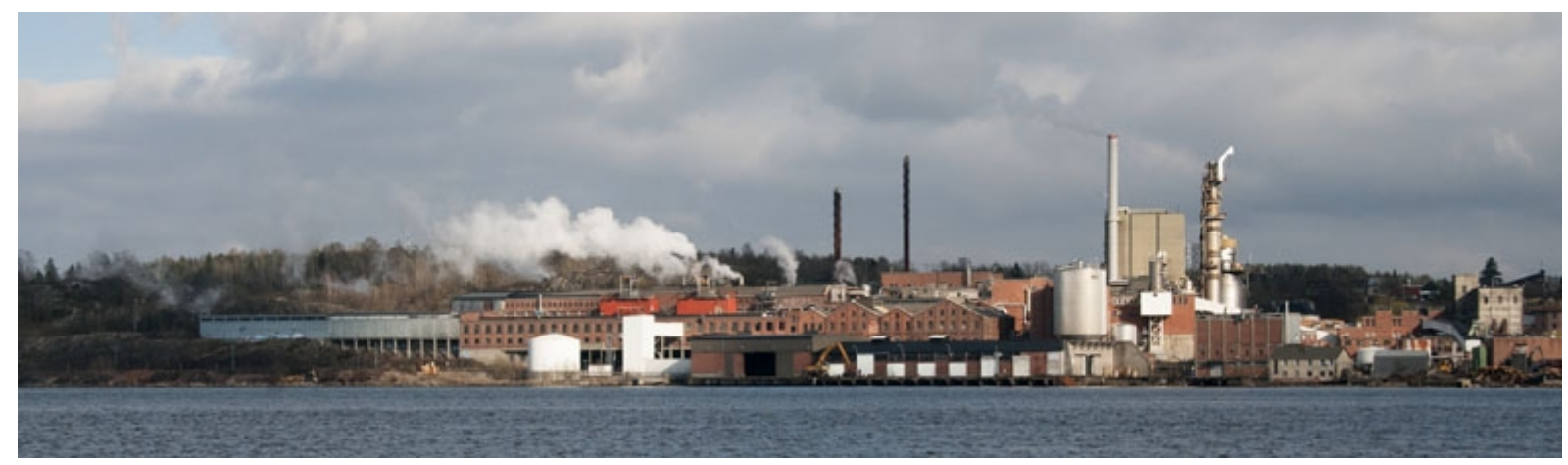

Figure 7. M. Peterson \& Søn when still in operation. Moss was famous for its sulfate boiling method, which was the starting point for the well-known 'smell of Moss' (mosselukta). Photo: Roderick Ewart Østlandsmuseene.

\section{Larger plans for the transformation of Verket}

Höegh Property has owned parts of M. Peterson since 2006. Since industrial production ended in 2012, Höegh has worked on plans for new uses of the factory site. The site is named after the old iron works that were situated here before M. Peterson \& Søn started up, and the first section of apartment buildings that are ready for sale is named 'The Foundry' (Støperiet), after the first iron production that took place there. When the planning started, the municipal area plan for the town centre did not include the site. According to the owner, the new part of town will cover $270,000 \mathrm{~m}^{2}$, and the building is expected to finish in 2038 (information from short telephone conversation with an employee of Höegh Property). Parallel with the cleaning up of the brownfield and the shipping of much of the machinery from cellulose production to China, the planning of the new neighbourhood started. This renovation process lasted 1.5 years. One of the first tasks completed was the restoration of the workers' houses at the iron works situated in the street 'Verket', which constitutes the east border of the site. According to Höegh, the houses now have high modern standards and are considered attractive to rent. The exteriors are preserved, and their location alongside Konventionsgaarden and the bridge across the massive waterfall adds a particular atmosphere to the area, described by the owner as 'surrounded by history'. Old buildings add atmosphere and 'create a place that fills people with enthusiasm' (respondent 3). When planning started, County Heritage Management estimated that many of the industrial buildings were too dilapidated to be preserved. Höegh ended up with three red brick buildings, Verket Scene being one of them. Directives concerning the restoration related only to the exterior, since much emphasis was placed on facilitating new uses for these buildings. Höegh was generally satisfied with this, since the building standards were good. The municipality is pleased that Höegh is the property owner, since Höegh has a long-term perspective. The firm is described as very cooperative, and the fact that principal staff are from Moss is considered to play a central role. These staff grew up with the town's history and know that everyone in Moss has a relationship with the site (respondent 5).

When it is finished, the site will contain more than 2,000 homes. The area is envisioned as a new part of town, with businesses, offices, shops and restaurants offering various cultural and recreational services. Negotiations are being carried out (autumn 2017) to locate the Norwegian Police University College here. A decision to move the university college to Moss is expected to have major positive effects for the area, adding activity and vitality. The municipality stresses that the area is not going to turn into a rival business area, and consequently only certain parts are regulated for commerce (Figure 8).

The apartments vary both in size and price, with the aim of obtaining a diverse mix of residents with different expectations and needs. The apartments are advertised as being of a high architectural standard and are being built in 'different heights, designs and materials', 
which 'creates an exciting variety, in contrast to the monotony often featured in many new housing projects'. The façades vary: some are in brick, others in wood, others in sheet metal.

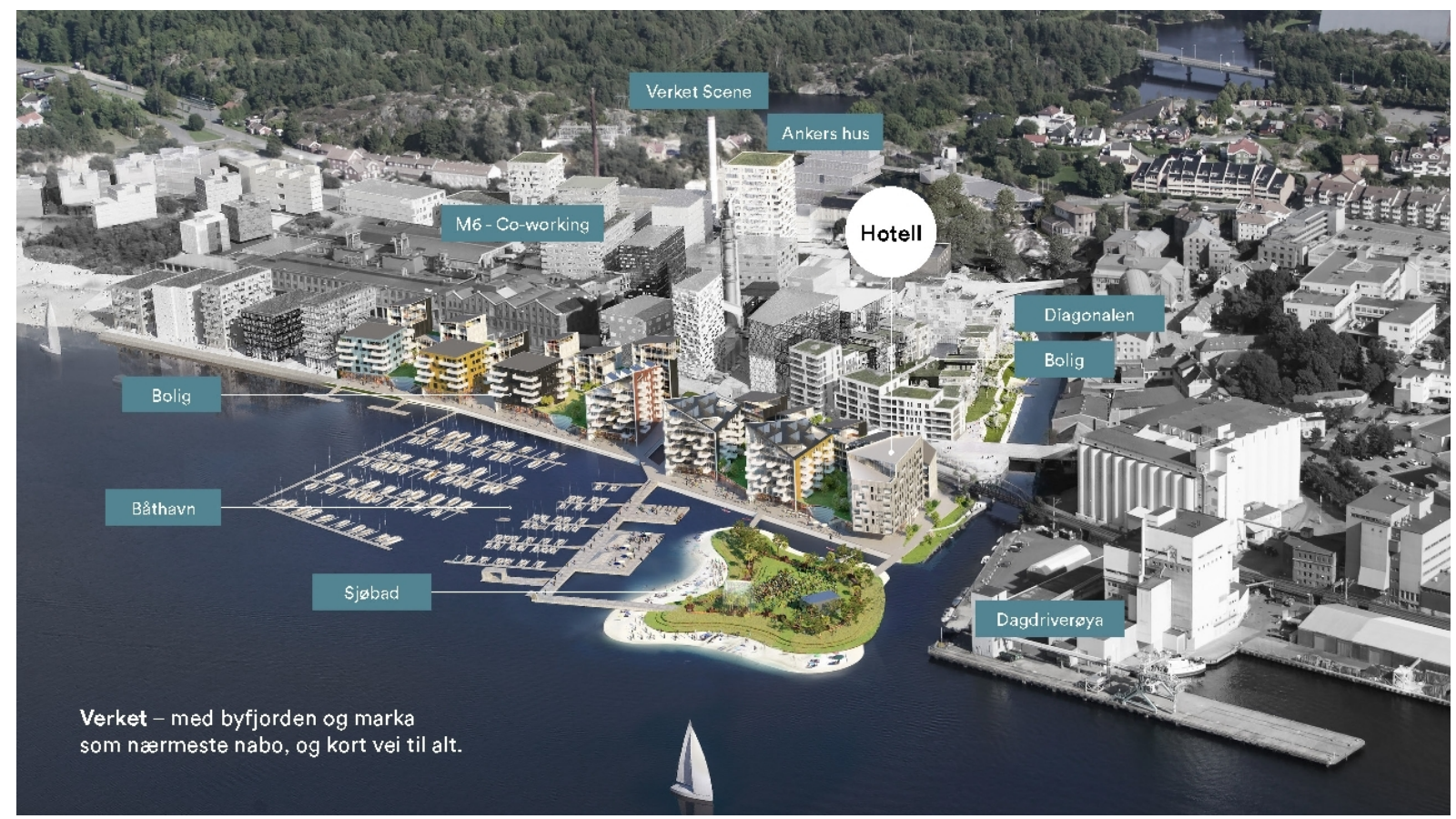

Figure 8. The plan, as imagined by the property developer Höegh, of how the area will look when it is fully developed. However, adjustments will likely take place during the process (respondent 3 ). Photo: Höegh Eiendom.

If the plans prove correct, the area will attract people from all over town, not just residents. The bridge(s) that are planned will be constructed at the lower part of the river and will connect the new neighbourhood to Møllebyen. Møllebyen is a restored industrial mill where the town museum, a literature centre, a library and other cultural facilities are situated. The bridge will connect the paths that are planned along the sea front on both sides of the river, part of it named 'the Harbour Promenade'. Other pedestrian paths are planned in a green corridor along the northern side of the river. The seafront is considered one of the major factors that will make the area attractive, and the brochure tells us that homes are available 'right by the sea, in the middle of the city'. A harbour is planned, alongside a small, filled-in island with beaches, which will attract families with children and will facilitate fishing. A sharing economy model introduced for the residents will make it possible to rent kayaks, bicycles and even cars. With plenty of services just around the corner, an available car-sharing service and the town centre within walking distance, the necessity of owning private cars in the future is in doubt. The first phase of the building project is situated near Verket Scene and will be ready in September 2018 (respondent 5; Höegh Eiendom Øst, n.d.).

\section{Verket Scene}

This building was partly in use by Peterson \& Søn for administration. It is located on a site called 'Culture Square'. Verket Scene is an answer to the need, announced by the municipality when the transformation of the site began, to pay special attention to cultural services (Figure $9,10,11)$. It was considered complementary to the provisions found in Møllebyen, where the town's many cultural institutions are housed. The municipality underlined the importance of ensuring public space and required a green corridor 15 meters wide to prevent privatisation. A detailed area plan has been drawn up for the area around 'Culture Square' and Verket Scene, 
while a coarse-meshed area plan is available for the rest of the area at the moment. Höegh's intention was to open up this area for everyone, and the media have reported that many people who had never been there before have now visited (respondent 5).

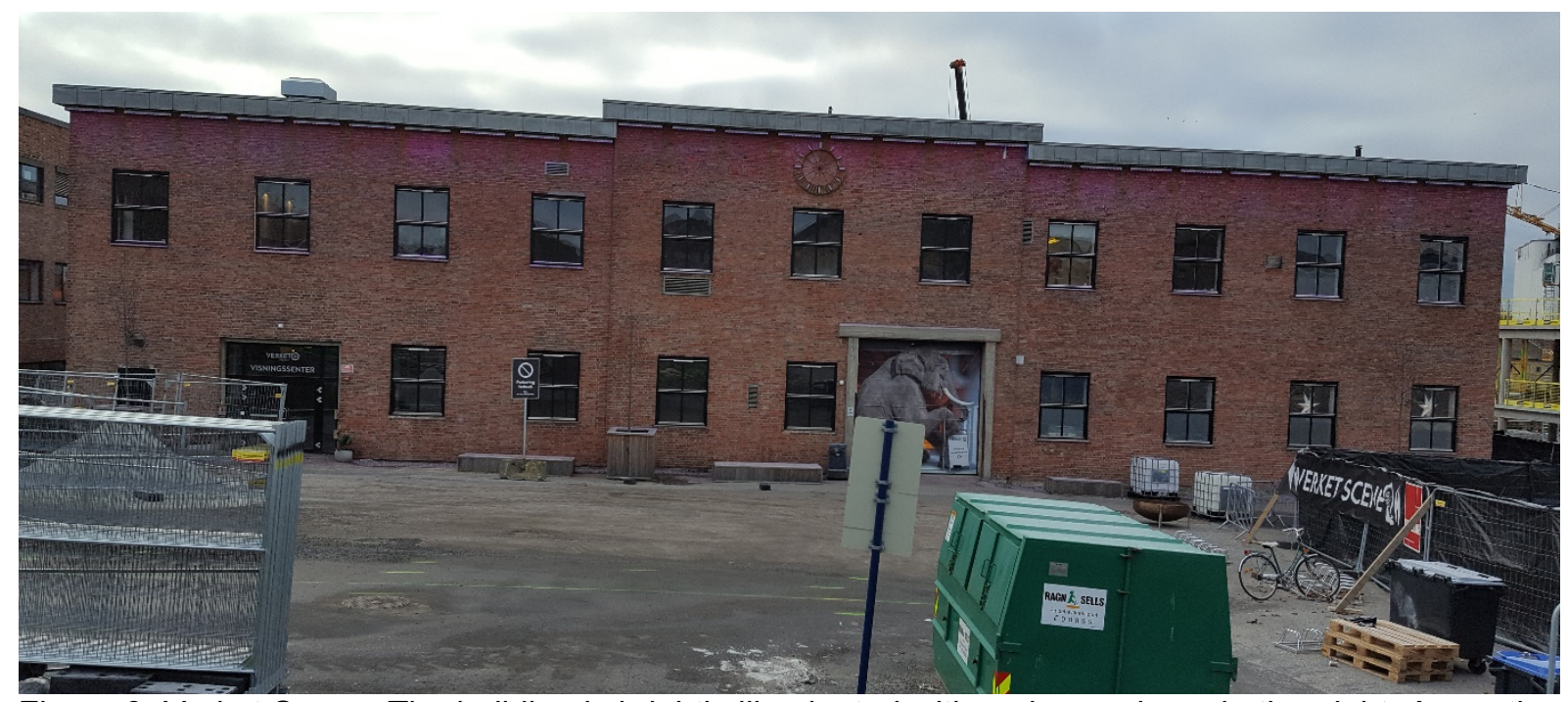

Figure 9. Verket Scene. The building is brightly illuminated with various colours in the night. A creative decoration in the front is an artistic interpretation of Peterson \& Søn's elephant logo. Photo: NIKU.

Til bruk i Hovedport og po̊ Vei- og målestasjon ved Peterson Linerboard AS, Moss

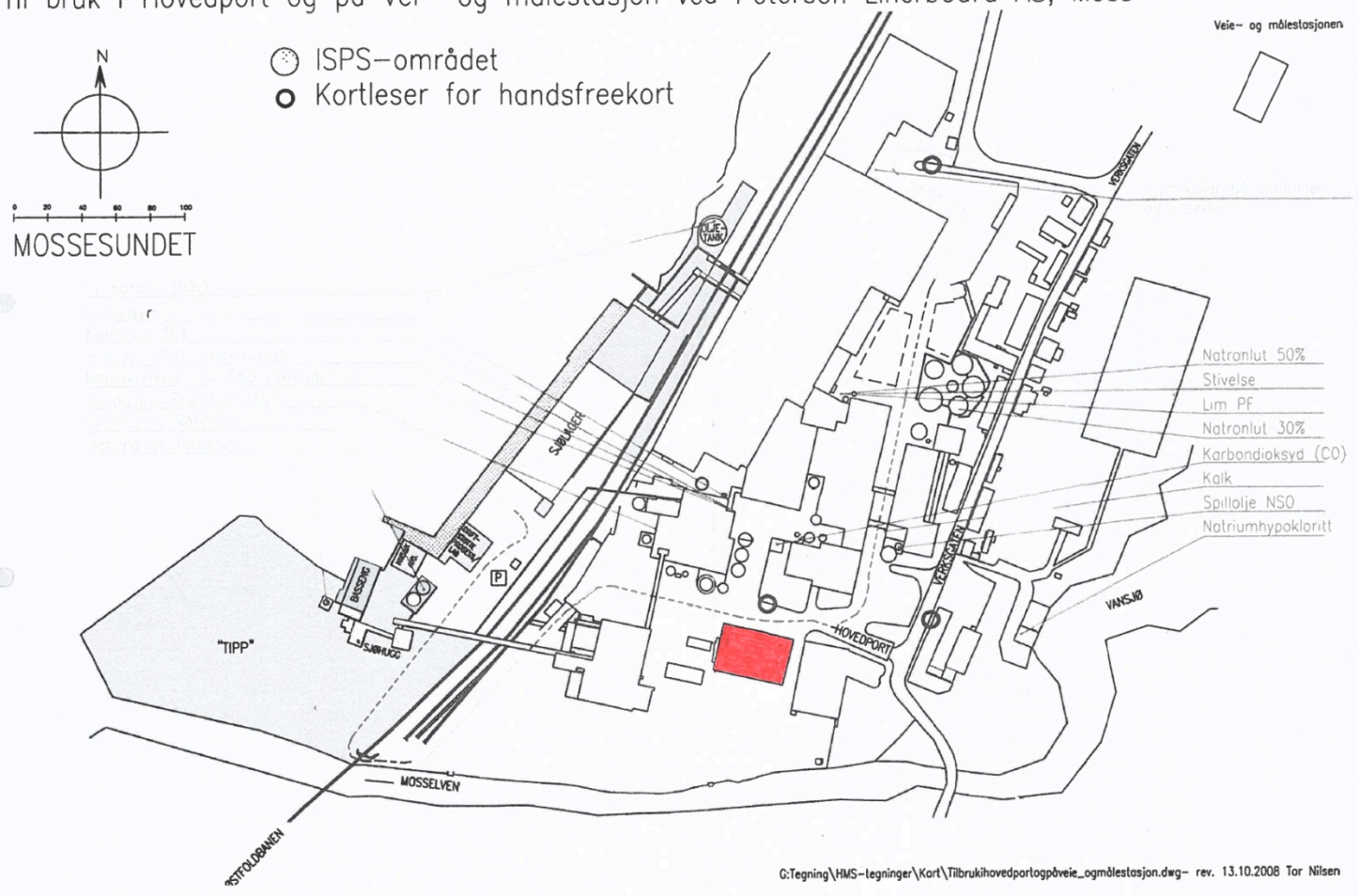

Figure 10. The map of Person \& Søn's factory. The building marked in red today houses Verket Scene. From the exhibition 'Fra Moss jernverk til Petersons Moss' in the street 'Verket' number 20. Illustration: $\varnothing$ stfoldmuseene, Moss by og industrimuseum. 


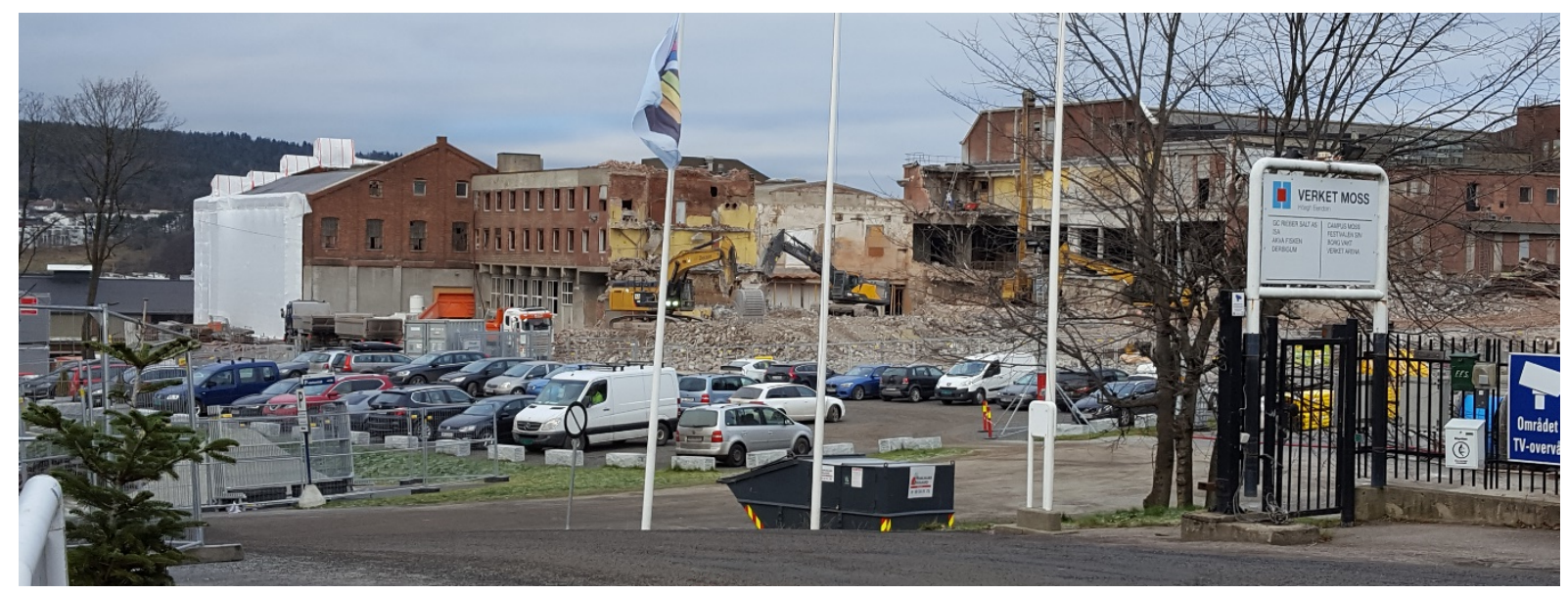

Figure 11. Verket Scene contributes today to opening up an area that was once closed for most people in Moss. Photo: NIKU.

The building is still owned by Höegh Property, which has been looking for suitable activities for the building, and it is now rented to a group of four local culture personalities. Höegh knew that 'they were the type who would get things done' (respondent 3). The scene intends to strengthen a tradition Moss already has, one associated with rock, pop and youth culture (Figure 12).

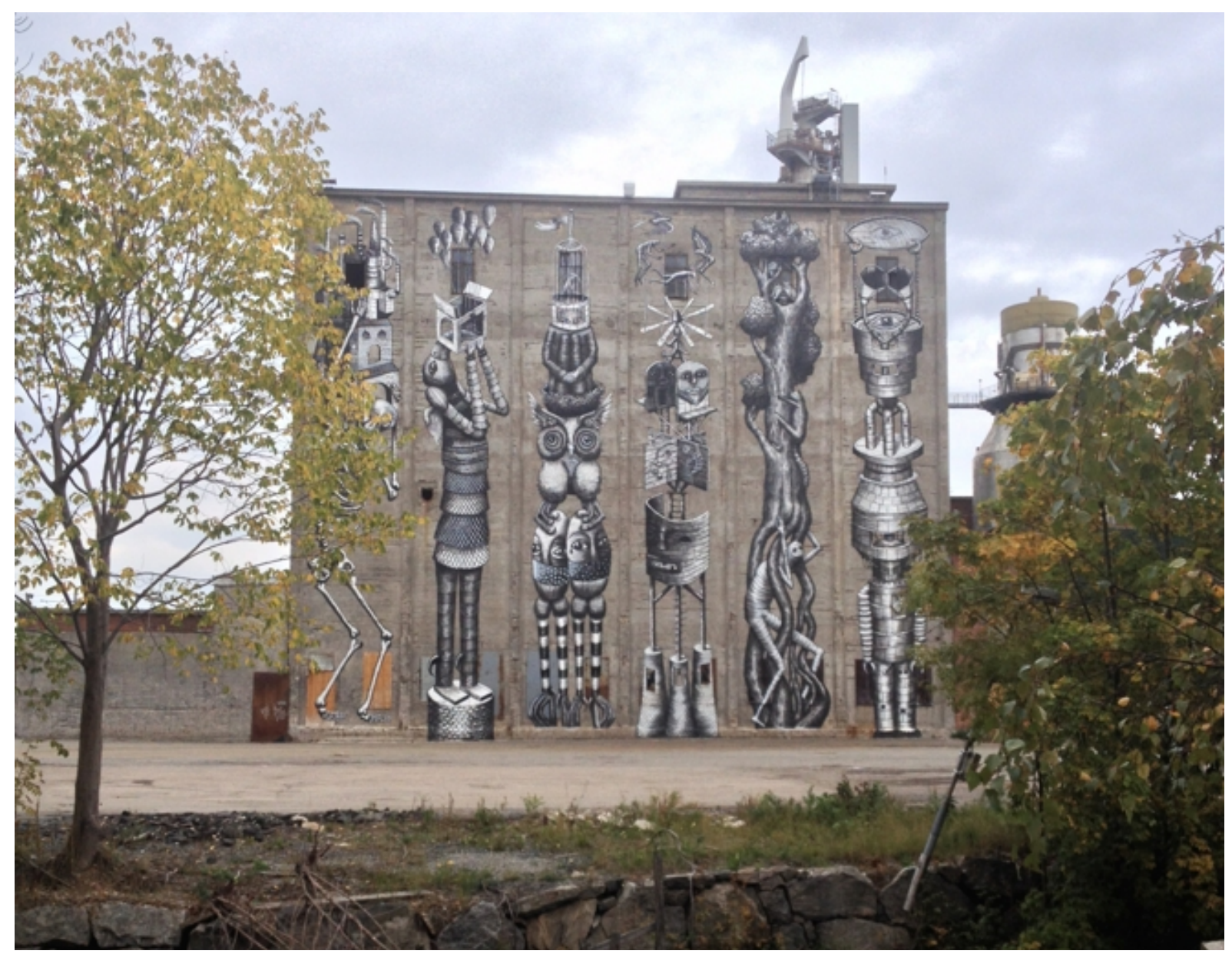

Figure 12. $750 \mathrm{~m}^{2}$ mural painting by artist Phlegm (pseudonym). Finished in nine days in July 2014 . Photo: Wikimedia Commons. 
The building performs several functions. Verket Scene consists of a large hall with a stage that is rented out for various cultural events, both theatrical and musical, and for private functions (parties, anniversaries) (Verket Scene, n.d.). The municipality often uses it to arrange seminars and courses. On the second floor are two dance halls, both of which are rented out. On the lower floor, a studio is rented out to a sculptor.

The last part of the rehabilitation took place last year (kitchen, toilets, back stage area, etc.). The regulations for the rehabilitation of such buildings for public use are complicated. Fire regulations are one such issue. Höegh has been intent on rehabilitation, however: 'There is a special charm with old buildings', and it is 'cool with history in the walls' (respondent 5). Höegh Property is also located in a part of the building with an office, rehabilitated in a delicate modern style, and an exhibition hall.

There are ongoing discussions concerning other historic remains from the industrial period. One structure, named 'Kamyr', is the last of three elements of the original boiler used in the production of cellulose. An application was recently sent to The Heritage Fund to obtain additional funding, partly from the Directorate for Cultural Heritage, and partly from local money. The first objective, however, is to ensure Kamyr's future. Then, new options for use for tourist purposes can be discussed (respondent 5) (Figure 13).

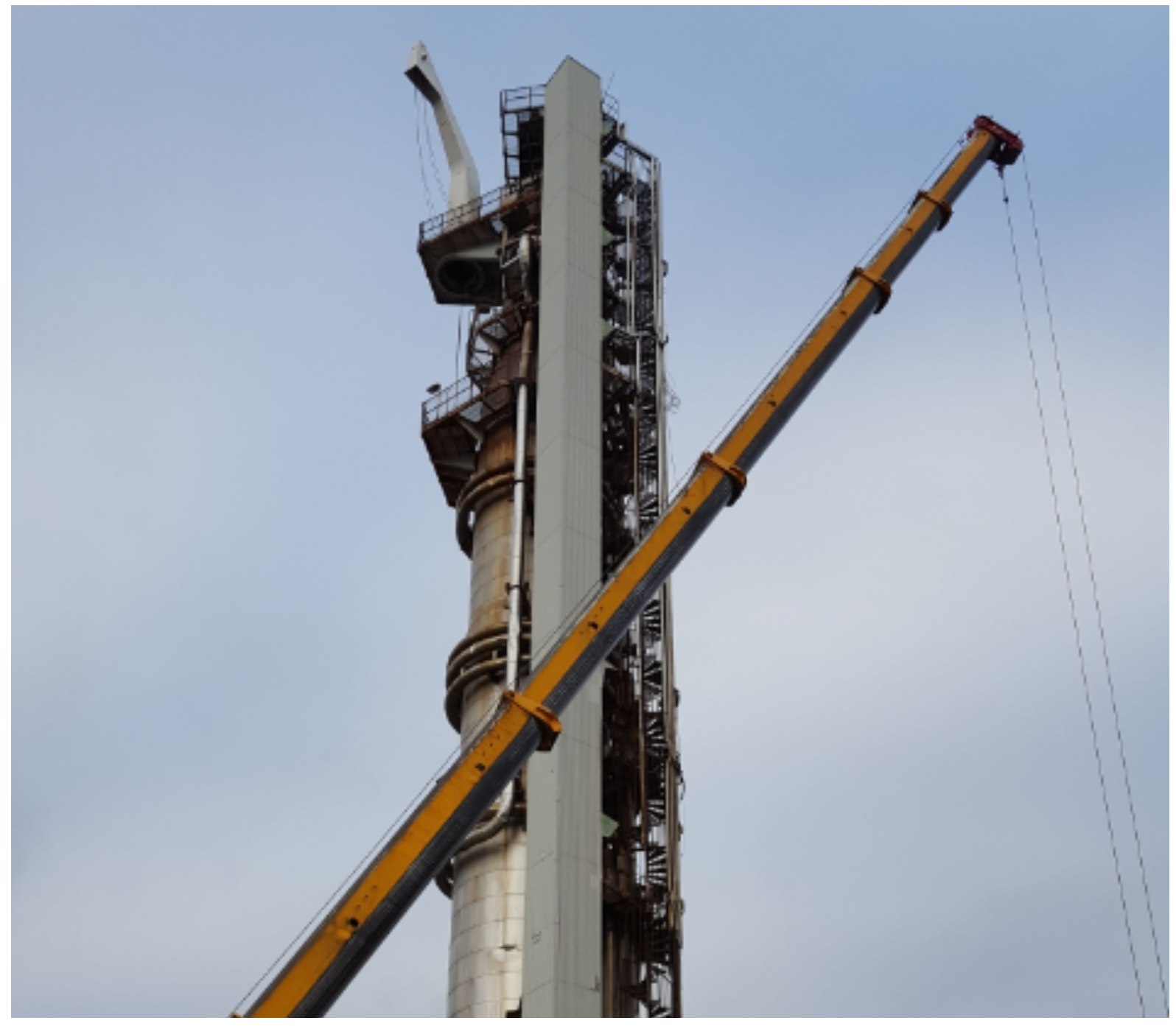

Figure 13. 'Kamyr' is the last part of three elements of the original boiler from 1971 used in the production of cellulose. It is possible to imagine different creative uses in the future. Photo: NIKU. 
The old factory building and the surrounding area include many alternative public spaces for various cultural events. The Moss town and industrial museum rents one of the workers' dwellings from Höegh Property, where residents and visitors can learn about the history of the industrial period and some of the people who lived in the street 'Verket' when the factory was running (respondent 4). Verket Scene intends to plan a programme that will reach a wide audience, and some events will take place in the yard behind the Konventionsgaarden and in the street 'Verket'.

Another of the remaining buildings is the 'Paperhall'. If the Norwegian Police University College moves in, then this building may be suitable as a sports venue, including a gun range, swimming pool, etc. (respondents 3, 4, and 5).

\section{Discussion}

We will start by comparing the two transformation projects in view of the questions we asked initially. If we start by looking at the cultural provisions offered by the two cultural venues, there is a marked difference. The old Spirit factory is used strategically as an element in a larger project of promoting Skien as an artist city. Providing affordable studios and good working conditions to professional artists has been favourably received. In Moss, Verket Scene can be seen as one element in a wider municipal plan to enhance culture in its broadest sense: art, architecture, creative industries, museums, libraries, archives, sport, films and performing arts (Stevenson, Rowe, \& McKay, 2010). Verket Scene is an arena for a local audience with a broad interest in entertainment and culture.

The fact that both transformation projects are in their early stages makes it hard to answer definitively whether they have managed to reach a diverse population. Concerning 'Spriten', there is a chance that a new college and a pedestrian path along the river will bring a younger and more diverse audience into the area. In Verket Scene, some of the cultural programme targets families with children; and according to the planning document, the developer is targeting a diverse age group. Ethnic pluralism is not a subject mentioned; however, we may assume the broad range of activities is able to draw diverse audiences when the projects are completed. Undoubtedly, there may be a risk of gentrification due to a deregulated housing market; however, the developers' interest in diversity may - to some extent - prevent such processes from materialising. At Klosterøya in Skien, for example, there are plans to establish an institution for people suffering from different kinds of drug addiction, which will secure diversity when it comes to 'economic classes'.

Concerning the historic dimension, the two projects have several commonalities: They are both situated on historic ground with a time arrow that stretches far beyond the modern industrial period (16th-18th centuries). The time perspectives are used strategically in various ways, including naming some buildings after their previous function. In Skien, the pedestrian steps from the main road to the new residential area are named Nonnetrappa ('the Nuns' Steps'), and in Verket the first part of the development is named Støperiet ('The Foundry'). Much contemporary urban transformation presupposes that new ways are found to emphasise and sometimes even magnify historic traces. Naming, contrasting old and new structures, and relocating then embedding historic fragments with symbolic meaning have become important means of mediating heritage (Swensen, in press). Such means can be used as key symbols to strengthen collective memories, place-attachment and the construction of narratives.

\section{Heritage and its tolerance level}

There are a number of new functions such buildings can fill, and according to Stratton (2000), it is essential to make well-considered, conscious choices regarding the intended degree of preservation. Since any adaptive reuse project is special, it is essential to clarify in the introductory phase which features need particular attention. Stratton (2000) specifies three different main strategies for reuse: The first is to look for a combination of various functions (such as offices, commercial premises, shops, service features, housing, culture and recreational 
venues, etc.). The second chooses to select a few buildings and structures as a starting point and then develops the area into larger neighbourhood districts. In the third, a combination of preservation and development is relevant, joining the old and new structures with park and recreation areas. Fragner (2012) found that, in practice, a combination of the three strategies often takes place.

When we compare the two transformation projects that have occurred on the large industrial sites, the degree of preservation is rather similar. Primarily single buildings have been selected for further use, while the others have been demolished. This means that the preserved buildings will, to some extent, end up in an altered urban fabric. There may be several reasons for this choice of strategy, such as the poor state of the remaining buildings and structures, the need for efficient use of the available area and cost estimations. Other options are possible even when the structures are bad; for example, keeping parts of a façade to provide an illustration of old building methods (respondent 4) or retaining some elements and structures from the old site (railway tracks, paths, ports, firm emblems, etc.) to symbolise the former activities that took place on the site. This refers us to the intended degree of preservation and the importance of discussing such matters in the early stages of the transformation (Fragner, 2012; Stratton, 2000).

\section{Culture - diversity and sustainability}

Fragner (2012) referred to the 'raw' character of industrial buildings as a special quality and identified it as 'the industry's aesthetics'. Other studies have confirmed that historic environments add a special quality that is appreciated by artists and various cultural workers (Berens, 2011; Brandser, Brekke, Homme, \& Nyrnes, 2015; Sørum et al., 2017): 'The physical environment is a prerequisite for their work, which is linked to unique qualities, low rents, oldage housing and historical presence' (Sørum et al., 2017, p. 2). The national guidelines concerning cultural policy and local practice might not always converge (Haugsevje, Hylland, $\&$ Stavrum, 2016). On the local, municipal level, a wide and inclusive definition of culture is used. It is generally considered to include much more than professional art forms. Practical issues, such as providing places for young people to meet and do things together, must be dealt with. At a municipal level, this creates an indistinct boundary between initiatives that belong to the social sector and to the cultural sector, indicating the importance of seeing national and municipal cultural policy in relation to one another (Haugsevje et al., 2016). Brandser et al. $(2015$, p. 110) referred to this as a socio-cultural tension in the national cultural policy. It appears as a tension between 'high' culture and popular culture/amateurs. This includes paying attention to creating venues where local cultural activities can take place, as opposed to giving priority to venues to house visiting national art performances. Brandser and colleagues also identified a value-orientated tension: different views concerning whether art should be considered a value per se (intrinsic value) or should be assessed by the use value it possesses (autonomy vs. utility). In the latter approach, art functions as a political-bureaucratic instrument for other goals.

As mentioned, there is now a burgeoning interest in cultural sustainability, not only concerning what might constitute the fourth pillar but also in other ways to inscribe culture into the sustainability agenda. One of the most recent attempts is the COST Action IS1007 'Culture in, for and as Sustainable Development' (Dessein et al., 2015, emphasis in original; Soini \& Birkeland, 2014). This was a European research network in the period between 2011 and 2015 that was aimed at highlighting European research 'in order to provide policy makers with instruments for integrating culture as a key element of sustainable development' (Dessein et al., 2015 , p. 6). However, without scrapping the fourfold model, the network developed two additional models corresponding to the different interdependent roles that culture may have in sustainable development. In the fourfold model, the cultural pillar is referred to as culture in sustainable development, while the second role is referred to as culture for sustainable development. Here, culture does not have its own pillar; rather, culture - broadly conceived serves as a mediator between the other pillars (Dessein et al., 2015, p. 30). While culture in the 
first role is considered in its own right, culture for sustainability is primarily considered by its effects in other policy fields than its own. In the final and third role that culture can have culture as sustainable development - culture is given an even more profound role $(2015$, p. 31$)$. Here, culture - in the anthropological sense - is the root of all human decisions and actions, and the distinction between the pillars begins to fade (2015, p. 29).

In Skien and Moss, it is evident that heritage and culture are treated as valuable in their own right - that is, culture in sustainability. Heritage and culture would still matter even if they did not contribute to other social and political domains (Belfiore \& Bennett, 2008, p. 7). Independent of whatever economic contribution heritage and arts might make, this is not the true nature of aesthetic and cultural experience (Skrede, 2016, p. 421). However, of equal importance: culture is valued for its contribution to attractiveness, place-identity, diversity, social well-being and economic growth - that is, culture for sustainability. Finally, culture as sustainability can be viewed at a more profound level. We can, for example, 'insist on a cothinking of environmental, social and cultural sustainability', and 'on how social life is embedded in particular places and situations' (Dessein et al., 2015, p. 31). As such, we may also view the projects in Skien in Moss as inspired by such a holistic approach.

\section{Conclusion}

This study has shown how heritage and culture are used to enhance sustainable urban development. Although the two cultural venues and the cities that have been examined vary in size and character, they have several commonalities. One is the emphasis that planners in the two cities have placed on local anchoring. The cultural services they offer are viewed as part of the larger cultural strategy of the city. While some specific art and cultural offers are situated in the new neighbourhood, others are found in the city centre. As an integrated service, they can reach a wider range of the population. The green dimension is another key issue. In Skien, the intention is to provide a walking path and river bed that will make the new neighbourhood easily accessible without using cars. The municipality in Moss has also cooperated with the property owner to ensure good integration of the services in the city centre and the new neighbourhood. Our two case locations, Skien and Moss, demonstrate how industrial heritage can work as a valuable resource in local communities. Industrial heritage may contribute to a flourishing cultural life and work as a reminder of past industrial history. The creative and artistic practices taking place in the old Spirit factory in Skien are virtual cultural sustainability in action. Not only is the building - with its cultural value - preserved, but it enables a flourishing cultural life to occur within the historical walls. In Moss, the citizens enjoy a new cultural scene for a diverse range of cultural activities. In both cases, the transformed industrial buildings provide an additional historical element. The adaptive reuse of industrial structures demonstrates that cultural sustainability is as important as the other sustainability goals - and equally important: the goals may cross-fertilise each other.

\section{Grete Swensen}

Research professor and ethnologist $(\mathrm{PhD})$

Norwegian Institute for Cultural Heritage Research

\section{Joar Skrede}

Research professor and sociologist $(\mathrm{PhD})$

Norwegian Institute for Cultural Heritage Research 


\section{References}

Amin, F., \& Ingdal, N. (2009). Kartlegging av innvandreres kulturarenaer i Follo. Oslo: Nordic Consulting Group, NCG. Retrieved from https://www.oppegard.kommune.no/www/oppegardkommune/resource.nsf/files/www8r9bsfinnvandreres_kulturarenaer/\$FILE/innvandreres_kulturarenaer.pdf

Arts Council Norway. (2013). En kunnskapsbasert kulturpolitikk. Kulturdepartementets eksterne FOU-utvalg. Oslo: Norsk Kulturråd.

Belfiore, E., \& Bennett, O. (2008). The social impacts of the Arts. An intellectual history. Basingstoke: Palgrave Macmillan.

Benton-Short, L., \& Short, J. R. (2008). Cities and nature (2nd ed.). London: Routledge.

Berens, C. 2011. Redeveloping industrial sites. A guide for architects, planners, and developers. Hoboken, New Jersey: John Wiley \& Sons, Inc.

Berg, Sveinung Krokann. (2017). Cultural heritage as a resource for property development. The Historic Environment: Policy \& Practice, 8(4), 304-322.

Brandser, G., Brekke, O. A., Homme, A., \& Nyrnes, A. (2015). Arena, kunst og sted. Norske kulturarenaer $i$ møte med kunstens nye krav. Kulturrådet. Bergen: Fagbokforlaget. Retrieved from http://www.kulturradet.no/documents/10157/275369ea-c792-4037-a351-e7d5fd1b5b32

Bratsberggruppen (n.d.) Klosterøya, Skien. Næringsparken i byen. Retrieved from http://www.bratsberggruppen.no/eiendommer/naeringsparker/klosteroeya-skien

Dessein, J., Soini, K., Fairclough, G., \& Horlings, L. (2015). Culture in, for and as Sustainable Development. Conclusions from the COST Action IS1007. Investigating Cultural Sustainability Finland: University of Jyväskylä.

Dryzek, J. S. (2005). The politics of the Earth: Environmental discourses (2nd ed.). Oxford: Oxford University Press.

Elkington, J. (1998). Cannibals with forks: The triple bottom line of the 21st century business. Gabriola Island, B.C.: New Society Publishers.

Flew, T. (2014). Creative industries - a new pathway, InterMEDIA, 42(1), 11-13. Retrieved from http://eprints.qut.edu.au/68631/1/Intermedia_CI_article_42_1_2014.pdf

Fragner, B. (2012). Adaptive re-use. In James Douet (Ed), Industrial heritage re-tooled. The TICCIH guide to industrial heritage conservation (pp. 110-117). Lancaster: Carnegie Publishing Ltd.

Haugsevje, Å. D., Hylland, O. M., \& Stavrum, H. (2016). Kultur for å delta. Når kulturpolitiske idealer skal realiseres i praktisk kulturarbeid. Nordisk Kulturpolitisk Tidsskrift, 19(1), 78-97.

Hawkes, J. (2001). The Fourth Pillar of Sustainability. Culture's essential role in public planning. Retrieved from http://www.culturaldevelopment.net.au/community/Downloads/HawkesJon(2001)TheFourthPillarOfSustaina bility.pdf

Hesmondhalgh, D. J. (2008). Cultural and creative industries. In The SAGE handbook of cultural analysis (553569). Leeds: Sage Publications Ltd. Retrieved from http://eprints.whiterose.ac.uk/42752/8/hesmondhalghDI5.pdf

Höegh Eiendom Øst. (n.d.). Verket. Støperiet. Bo på historisk grunn rett ved sjøen, midt i byen. Salgstrinn $3 \& 4$

Landry, C. \& Bianchini, F. (1995). The creative city. Wales: Demos Creative Commons.

Ministry of Culture. (2004-2005) Kultur og naering. St.meld. nr. 22. Retrieved from https://www.regjeringen.no/no/dokumenter/stmeld-nr-22-2004-2005-/id407136/

Ministry of Climate and Environment. (2004-2005). Leve med kulturminner. St.meld. nr. 16. Retrieved from https://www.regjeringen.no/no/dokumenter/stmeld-nr-16-2004-2005-/id406291/

Ministry of Culture. (2013). Kulturutredning 2014. Norges Offentlige Utredninger 2013:4. Oslo: Departementens servicecenter. Retrieved from https:/www.regjeringen.no/contentassets/1e88e03c840742329b9c46e18159b49c/no/pdfs/nou201320130004 000dddpdfs.pdf 
Ministry of Culture. (2017). Næringspolitisk råd for kulturell og kreativ næring (2015-2017). Innspill. Utg. Kulturdepartementet og Nærings- og fiskeridepartementet. Report 06/2017. Oslo: Departementenes sikkerhets- og serviceorganisasjon. Retrieved from https://www.regjeringen.no/contentassets/8aeb67b6217d41b29b18b5584a87f61c/naringspolitisk-rad-forkulturell-og-kreativ-naring.pdf

Ministry of Culture, Ministry of Trade and Industry \& Ministry of Local Government and Regional Development. (2007). Kultur og ncering. Retrieved from https://www.regjeringen.no/globalassets/upload/nhd/vedlegg/handlingsplaner2007/kulturognaering_handling splan_070625.pdf

Ministry of Culture, Ministry of Trade and Industry \& Ministry of Local Government and Regional Development. (2013). Fra gründer til kulturbedrift. Retrieved from http://www.regjeringen.no/upload/KUD/Samfunn_og_frivillighet/Rapporter/Fra_grunder_til_kulturbedrift_2 013.pdf

Nurse, K. (2006). Culture as the Fourth Pillar of Sustainable Development. Retrieved from http://www.ibrarian.net/navon/paper/2_Culture_as_the_Fourth_Pillar_of_Sustainable_De.pdf?paperid=181 07632

Oliveira, A., \& Paulino, F. (2017). European creativity and urban regeneration, The Journal of Public Space, $2(2), 127-140$

Ottersland, P. K. (2015). Union Co. - fra skog til papir. Arkivmagasinet 3/2015. Oslo: Riksarkivet. Retrieved from https:/dokumenteneforteller.no/2017/03/24/union-co-fra-skog-til-papir/

Østfoldsmuseene, Moss by- og industrimuseum (2015). Fra Moss jernverk til Peterson Moss. Eu utstilling om arbeid, dagligliv og industri. Østoldsmuseenes skriftserie nr. 12. Fredrikstad: Griff kommunikasjon.

Pratt, A. C. (2015). Resilience, locality and the cultural economy, City, Culture and Society 6(3), 61-67.

Preite, M. (2012). Urban regeneration and planning. In James Douet (Ed.), Industrial heritage re-tooled. The TICCIH guide to industrial heritage conservation (pp. 101-109). Lancaster: Carnegie Publishing Ltd.

Richards, G., \& Wilson, J. (2006). The creative turn in regeneration: Creative spaces, spectacles and tourism in cities. In M. K. Smith (Ed.), Tourism, culture and regeneration (pp. 12-24). Roma: CAB International.

Rypkema, D. D. (2006). Economics, sustainability, and historic preservation. Forum Journal, 20(2), 27-38.

Scott, A. J. (2000). The cultural economy of cities. Essays on the geography of image-producing industries. London: Sage Publications.

Skien Municipality. (2017). Kunstnerbyen Skien. Retrieved from http://www.skien.kommune.no/kunstnerbyen

Skjerven, A., \& Reitan, J. B. (2017). Introduction. In A. Skjerven \& J. B. Reitan (Eds.), Design for a sustainable culture. Perspectives, practices and education. London: Routledge.

Skrede, J., \& Berg, Sveinung Krokann. (2018). Cultural heritage and sustainable development: the case of urban densification. The Historic Environment: Policy \& Practice, 1-20. https://doi.org/10.1080/17567505.2019.1558027

Skrede, J. (2013). The issue of sustainable urban development in a neoliberal age. Discursive entanglements and disputes. FORMakademisk, 6(1), 1-15.

Skrede, J. (2014). The value of culture. Discourse approaches to culture, capital and urban change. (Doctoral thesis, Aalborg University, Aalborg).

Skrede, J. (2016). What may culture contribute to urban sustainability? Critical reflections on the uses of culture in urban development in Oslo and beyond. Journal of Urbanism. International Research on Placemaking and Urban Sustainability, 9(4), 408-425. doi: 10.1080/17549175.2015.1074603

Soini, K., \& Birkeland, I. (2014). Exploring the scientific discourse on cultural sustainability. Geoforum, 51, 213-223.

Sörum, N., Berglund, Y., \& Brembeck, H. (2017) Platsar kulturen i den nya staden? Fria kulturutöveras perspektiv på kulturens och kulturarvets roll i den hållbara staden. Gøteborg: Gøteborg Universitet. Retrieved from https://www.mistraurbanfutures.org/sites/mistraurbanfutures.org/files/platsar-kulturenstaden-comp-2017_0.pdf

Steveson, D., Rowe, D., \& McKay, K. (2010). Convergence in British cultural policy: The social, the cultural, and the economic. The Journal of Arts Management, Law, and Society, 40(4), 248-265. 
Stratton, M. (Ed.). (2000). Industrial buildings. Conservation and regeneration. London: E \& FN Spon.

Swensen, G., \& Berg, S. K. (2017). Use of redundant industrial buildings as injections into the cultural sector in Norway, Planning Practice \& Research, 33(3), 344-358.

Swensen, G., \& Stenbro, R. (2013). Urban planning and industrial heritage - A Norwegian case study. Journal of Cultural Heritage Management and Sustainable Development, 3(2), 175-190.

Swensen, G., \& Stenbro, R. (2015). Industrial heritage as qualifying elements in urban landscapes. In N. Patricios (Ed.), Architecture anthology 1. Architectural and urban theory (pp. 173-188). Athens Institute for Education \& Research (ATINER).

Swensen, G. (in press). The temporal dimension in planning for the compact city - a case study from Bergen, Norway. In K. Fouseki, T. S. Guttormsen, \& G. Swensen (Eds.), Heritage and sustainable urban transformations - Deep cities. London: Routledge.

Throsby, D. (2012). Heritage economics: A connectional framework. In G. Licciardi \& R. Amirtahmasebi (Eds.), The economics of uniqueness. Investing in historic city cores and cultural heritage assets for sustainable development. Washington, D.C.: The World Bank.

Uffelen, C., V. (2010). Re-use architecture. Berlin: Braun Publishing.

Verket Scene. (n.d.). Retrieved from http://verketscener.no/

Zukin, S. (2010). Naked city: The death and life of authentic urban places. Oxford: Oxford University Press. 